\title{
, \\ National Culture and the Market Development of Battery Electric Vehicles in 21 Countries
}

\author{
Adam Novotny ${ }^{1,2,3}$, Inez Szeberin ${ }^{4}$, Sándor Kovács ${ }^{5}$ and Domicián Máté ${ }^{2,6, *(\mathbb{D})}$ \\ 1 Institute of Economic Science, Eszterházy Károly Catholic University, H-3300 Eger, Hungary; \\ novotny.adam@uni-eszterhazy.hu \\ 2 College of Business and Economics, University of Johannesburg, Johannesburg 2006, South Africa \\ 3 Business School, Nord University, 8026 Bodø, Norway \\ 4 Robert Bosch Automotive Steering Kft., H-3300 Maklár, Hungary; szeberin_inez@outlook.hu \\ 5 Department of Economics and Financial Mathematics, Faculty of Economics and Business, \\ University of Debrecen, H-4028 Debrecen, Hungary; kovacs.sandor@econ.unideb.hu \\ 6 Department of Engineering Management and Entrepreneurship, Faculty of Engineering, \\ University of Debrecen, H-4028 Debrecen, Hungary \\ * Correspondence: mate.domician@eng.unideb.hu; Tel.:+36-(20)-9915258
}

check for updates

Citation: Novotny, A.; Szeberin, I.; Kovács, S.; Máté, D. National Culture and the Market Development of Battery Electric Vehicles in 21

Countries. Energies 2022, 15, 1539 https://doi.org/10.3390/en15041539

Academic Editor: Edmundas

Kazimieras Zavadskas

Received: 11 January 2022

Accepted: 18 February 2022

Published: 19 February 2022

Publisher's Note: MDPI stays neutral with regard to jurisdictional claims in published maps and institutional affiliations.

Copyright: () 2022 by the authors Licensee MDPI, Basel, Switzerland. This article is an open access article distributed under the terms and conditions of the Creative Commons Attribution (CC BY) license (https:// creativecommons.org/licenses/by/ $4.0 /)$.

\begin{abstract}
Electric vehicles (EVs) have become a symbol of the fight against climate change. However, in many countries, the market development of EVs is sluggish, and adoption rates greatly vary worldwide. This study examines the impact of Hofstede's six dimensions of national culture on the development of the electric car market using sales data from 2019 and 2020 in 21 OECD countries. Results of (OLS) linear regression analyses show that uncertainty avoidance, individualism, masculinity, and indulgence have a significantly negative impact on the sales of battery electric cars, while long-term orientation positively influences their market share. The results indicate that national culture is an important cross-country factor that influences the rate and direction of the adoption electric cars. The research also explains how cultural values are translated into the purchase of EVs and provides marketers and policymakers with an insight into how they can increase the spread of alternative-fuel vehicles.
\end{abstract}

Keywords: battery electric vehicles (BEVs); national culture; Hofstede; OLS linear regression

\section{Introduction}

The first electric cars were introduced in the mid-1830s and soon outsold their gasolineand steam-powered rivals in the USA [1]. However, the spread of EVs declined or remained slow during the 20th and early 21st centuries because of the high total costs and limited technology performance, including low top speed and short range [2]. Today, because of further developments in lithium-ion battery technology [3], electric vehicles (EVs) have the potential to become a suitable instrument towards a more sustainable future of mobility, and especially small-size battery electric vehicles (BEVs) [4].

National and local governments worldwide have increased their efforts to speed up EV usage. From 17,000 electric cars in 2010, the number of EVs have increased to 10 million globally by 2020. According to the Sustainable Development Scenario (SDS), the global EV fleet will reach a share of 12 percent, i.e., 230 million vehicles by 2030, excluding two/threewheelers [5]. Several European capital cities plan to ban the use of internal combustion engine (ICE) vehicles in city centres [6], and many countries intend to discontinue selling ICEs between 2025 and 2050. Despite these efforts, road transport is still not on track towards carbon neutrality by 2050 in most countries, and reaching targets requires more aggressive actions, especially regarding heavy vehicles [7].

While EV sales seem to have grown rapidly around the world, the uptake of electric cars is rather low in most countries, with an uneven market share and highly different 
diffusion rates across countries [8]. In this study, we aim to better understand the reasons behind the pronounced country differences in electric car penetration rate by focusing on how national culture impacts the spread of BEVs. Research on ecological innovations (eco-innovations), i.e., innovations with a lower environmental impact [9], is rather scant compared to "ordinary" innovations. There is a growing body of research on the diffusion of eco-innovations worldwide emphasizing the importance of the national and regional cultural context $[10,11]$. The role of culture is particularly important in the case of driving and the development of EV markets. Automobiles are both a functional technology for providing mobility and a way of expressing social status and cultural identity [12]. Whilst global consumer culture impacts the "driving culture" and consumer decision making process uniformly worldwide [13], there are robust country-specific differences in overall usage and attitude to eco-innovations, including EVs [14]. Rezvani et al. [15] emphasise the need to explore and compare the symbolic meanings attached to EVs in diverse cultures since symbolic meaning is context dependent. According to the extant literature, national culture affects the innovation adoption rate, the adoption process [16], and differences in sustainable consumption [17]. The acceptance of EVs differs between countries, and cultural characteristics should be considered when promoting electric vehicles [14]. Gnann and Plötz [18] call for research that uses quantitative evidence for factors influencing EV diffusion.

We build our analysis on Hofstede's original [19] and extended six-dimension models [20] of national culture to better understand the interplay between cultural orientations and the adoption of electric vehicles. We model how contextual influences in various countries may favour or inhibit the translation of cultural values into EV buying decisions. Using cross-sectional data from 2019 and 2020 of 21 countries, we can assess the impact of culture in a larger context (i.e., social, and environmental influences on the consumer) on the EV markets. Our research contributes to the emerging literature of the determinants of the adoption of EVs and eco-innovations in general.

We test six hypotheses concerning the impact of the cultural dimensions proposed by Hofstede et al. [20], namely, power distance, uncertainty avoidance, individualism vs. collectivism, masculinity vs. femininity, long-term vs. short-term orientation, indulgence vs. restraint, on the market share of EVs. We found that in addition to wealth (GDP/capita), cultural values significantly impact the adoption of EVs. The results support prior findings that the demand for innovative, environmentally friendly products are unstable and vary from culture to culture [21] and show how different cultural orientations affect green consumer behaviour in the automotive market.

This work offers several contributions. It enriches the longstanding scholarly interest in the linkage between national culture and people's ability and willingness to protect the environment [22]. The study focuses on EVs that are slowly growing in popularity worldwide, and their use may be over-represented in cultures that foster normative beliefs and the development of self-identities that encourage more environmentally responsible behaviours [23]. We add to this research at the macroeconomic level by examining the impact of cultural orientations on the market share of EVs. Prior studies have mainly focused on the individual (demographic, psychological, socio-demographic) characteristics of EV buyers (e.g., [15,24,25]), implicitly assuming that preferences would result mainly from personal attributes, which is not necessarily the case.

Based on our quantitative study of 21 countries, we identify cultural dimensions that significantly impact BEV sales rates in a country based on Hofstede's works. This way, we point to both the facilitators of and impediments to the adoption of electric cars at a national level. Our method is novel as we involve all six cultural dimensions and test them in 21 countries, which represent most of the global EV market. Whilst EVs can include any road-, rail-, sea-, or air-based vehicle that is at least partly powered by electricity [6], in this paper, we focus on electric road transport and BEVs, which are fully powered by electricity. BEVs are considered more environment friendly than ICEs because they have no tailpipe emissions and no direct reliance on fossil fuels. 
The article proceeds as follows. The next section shows how previous empirical research regarding the impact of national culture on EV adoption explain country differences in EV market share. Six hypotheses concerning how specific cultural dimensions affect EV sales are also outlined. Next, the variables and sample are presented along with the analyses carried out to test the hypotheses. The hypotheses are then tested by means of regression analysis in the following section alongside a discussion of the results. The limitations as well as implications for future research and practitioners conclude the article.

\section{Literature Review and Hypotheses}

In developed countries, people are increasingly encouraged to acquire a greener, more environmentally friendly consumer behaviour characterised by lower environmental impact, including $\mathrm{CO}_{2}$ emissions [14]. Environmentally conscious consumers purchase goods and services they perceive to have a positive or less negative impact on the environment [26]. Besides green attitudes and lifestyles [17], consumers' innovativeness [27], experience [28], gender, age, marital status [29], profession, place of living, household type, driving habits, socio-economic status [30], social norms, and the willingness to comply with the norms [31] were all found to impact EV adoption. The market share of EVs is also influenced by government strategies and subsidies [32], including ownership tax benefits, as well as competitiveness factors related to the technology itself, such as purchase price [33], operating costs [34], charging infrastructure, travel range [18], and residual value [35]. Consumers raise concerns about the recycling of batteries, the pollution caused by battery production, the ecological footprint of batteries [36], the social and environmental consequences of mineral exploitation, and the limits of mineral resources [37]. Franzó and Nasca [38] affirmed that EVs have a better environmental performance in terms of $\mathrm{CO}_{2}$ emissions than internal combustion engine vehicles over the whole life cycle of the product; however, the link between $\mathrm{CO}_{2}$ emissions and EVs can vary depending on the country observed [39].

There are several empirical studies in the literature that show how national specificities can influence country differences in EV diffusion. In Italy, Danielis et al. [40] found that financial incentives have a more considerable impact on the probability of purchasing an EV than technological improvements. In India, the pricing of EVs is not a major issue in preventing consumers from purchasing EVs [41]. In China, most consumers consider switching to greener cars but are more likely to buy hybrid cars than pure electric vehicles $[42,43]$. Environmentally friendly technologies are more attractive to consumers in California who engage in pro-environmental and technology-oriented lifestyle practices as well as to people open to lifestyle changes [44]. The willingness to try new technologies increases the likelihood of adopting EVs in Norway; however, environmental concerns do not [45]. Government support was found to be critical to overcome the barriers of promoting EVs in Russia [46].

A few studies specifically focus on the role of culture in EV adoption. Barbarossa et al. [23] compared consumers in Denmark, Belgium, and Italy to assess significant crossnational differences in EV adoption intention and explain dissimilarities using Hofstede's national cultural dimensions. Busse et al. [47] also found evidence for culture-related differences in the adoption behaviour of eco-innovations between German and Chinese consumers; e.g., in cultures with a high degree of collectivism, friends and family have a much stronger influence on the intention to adopt eco-innovations than in individualistic cultures. McLeay et al. [14] suggest that future studies about eco-friendly consumption should pay more attention to the cultural context of previous findings. Relying on a nationwide survey in China, Qian and Yin [48] emphasise that public policy and social marketing efforts should consider cultural values in promoting environmentally sustainable innovative technologies.

There are several definitions of culture, which typically include values and norms; i.e., shared conceptions and beliefs about what is good, wrong, appropriate, or worthwhile regarding human behaviour and standards of behaviour [49]. Hofstede studies culture at the 
national level and defines it as "the collective programming of the mind that distinguishes the members of one group or category of people from others" [50]. In the following, we outline and explain our six hypotheses relating to the impact of different cultural dimensions (power distance, uncertainty avoidance, individualism vs. collectivism, masculinity vs. femininity, long-term vs. short-term orientation, and indulgence vs. restraint) on EV adoption. We approach the impact of culture on EV adoption through its role in innovative and environmentally conscious behaviour.

The first cultural dimension, power distance, refers to the degree to which the less powerful members of organisations and institutions (e.g., the family) accept and expect that power is unequally distributed. In societies with a more considerable degree of power distance, status is essential, and people tend to be less innovative and less open to new products and technologies [51]. Rinne et al. [52] found a strong negative relationship between Hofstede's power distance and the Global Innovation Index. Societies with high respect for authority have a weaker capacity for debate on social and environmental issues [53] and a smaller social and institutional capacity for environmental sustainability [54]. Values promoting "green" and sustainable consumption are found to be more widespread in egalitarian countries [55]. Higher power distance is associated with lower national income (wealth) [56] and weaker ability for both sustainability and innovation [57], and hence we assume that it will also negatively affect EV adoption.

Hypothesis 1 (H1). Countries with greater power distance have a lower EV adoption rate.

Uncertainty avoidance, a society's tolerance for ambiguity, is the extent to which culture programs its members to feel either uncomfortable or comfortable in unstructured (novel, unknown, or surprising) situations [56]. On the other hand, if a culture is characterised by strong uncertainty avoidance, people will try to minimise the possibility of situations different from "normal" by applying strict behavioural codes, laws and rules, and disapproval of deviant opinions. Prior research found that consumers in uncertainty avoidant cultures are less innovative [58] and have a weaker affinity to new technologies, such as e-commerce [59]. According to the data of the World Values Survey, uncertainty avoidance is not related to the propensity to support sustainability initiatives [60]. However, Vachon [61] found that a nation's high uncertainty avoidance is positively related to sustainable and responsible corporate practices. Since there is a significant amount of financial, psychological, and other risks associated with buying eco-friendly cars [23], we assume that uncertainty-avoidant societies are less likely to adopt them.

Hypothesis 2 (H2). Countries with greater uncertainty avoidance have a smaller EV adoption rate.

Individualism versus collectivism refers to the degree to which people in a society are integrated into groups. In individualistic cultures, the ties between individuals are loose, and everyone is expected to look after their immediate environment and family [56]. Some prior findings (e.g., [51,58]) associate consumer innovativeness with individualistic cultures. A longitudinal study of 62 countries by Taylor and Wilson [62] shows that individualism has a strong, significant, and positive impact on innovation; but certain forms of collectivism can also foster innovation at the country level. Regarding sustainability, Soyez [63] claims that an "ecocentric" value orientation is more likely to emerge in countries that hold individualistic values, while an "anthropocentric" value orientation is noticeable in countries with collectivistic ones. Interestingly, environmental activism is much more prevalent and diverse in individualistic cultures than collectivist ones [53]. Nevertheless, Nguyen et al. [64] found that collectivist cultural values positively impact environmental attitudes. In cultural collectivism, where the needs and wants of the group are deemed more important than those of the individual, green consumption is more supported [65]. A survey by Higueras-Castillo et al. [66] in three countries (Germany, Mexico, and Spain) confirmed that countries with a higher level of collectivism have more assertive intentions and eco-friendly behaviours regarding renewable energy technologies. Consumer-level 
collectivism has been found to positively influence attitudes to eco-friendly cars; however, eco-friendly consumers also consider other features such as performance and design [67]. Individualism seems to positively impact innovative behaviours, but more recent findings associate collectivism with environment friendly lifestyles.

Hypothesis 3 (H3). Countries with a more individualist culture have a lower EV adoption rate.

The masculinity versus femininity dimension refers in society to the distribution of values between the sexes. While typical women's values tend to be similar in different societies, men's values change considerably from one country to another, from being very assertive and competitive (i.e., very different from women) to modest and caring (i.e., similar to women) [56]. The strong pole is called "masculine" in Hofstede's model, and the modest, caring pole is called "feminine". Studies on the link between masculinity and innovation have been mixed, either finding no relationship between the two or indicating that feminine cultures may be more favourable to innovation [68,69]. In masculine cultures, consumers prefer economic growth over environmental sustainability [70], and firms tend to focus more on material goals [71] and slowly adopt costly green technologies [72]. Cars have been traditionally associated with men and masculine subcultures [73]. However, EVs used to be associated by manufacturers with women, who were viewed as homemakers who do not make frequent or long trips and hence are pleased with less competitive but cleaner cars as compared to men who regard power, range, and the economy more critical [74]. Since achievement and status can be demonstrated by possessing the most novel products, expensive EVs can become popular in masculine cultures [75]. A Belgian study found that women are more likely to drive EVs than men [24]. Gender is a significant driver of acceptance of EVs, especially in women, who have higher environmental consciousness than men [76].

Hypothesis 4 (H4). Countries with a more masculine culture have a lower EV adoption rate.

The long-term versus short-term orientation dimension has been related to Confucianism [77]. Future-oriented cultures focus on adaptation to circumstances, learning, perseverance, and thrift, while past-oriented and present-oriented cultures respect traditions and the home nation and accept universal guidelines on good and bad [56]. Bukowski and Rudnicki [78] show that long-term orientation is a strong positive predictor of national innovation intensity and highlight the need to advance the understanding of the causal mechanism between culture and innovativeness to guide further theoretical and empirical analysis. Long-term orientation has a significant positive impact on environmentally sensitive consumer behaviour too [79]. A Vietnamese study [64] found that consumers with greater adherence to long-term orientation are more likely to engage in green purchase behaviour because of their positive environmental attitudes, solid subjective norms, and tolerance of inconvenience associated with eco-friendly products purchase. A Chinese study of private firms confirmed that proactive environmental strategy does not happen without commitment and long-term orientation [80]. Long-term oriented people in general are more likely to develop values and attitudes about protecting the natural environment [81].

Hypothesis 5 (H5). Countries with a long-term orientated culture have a higher EV adoption rate.

The indulgence versus restraint dimension added more recently [56], complements long- versus short-term orientation. Indulgent societies (e.g., Mexico, Sweden, New Zealand, and Australia) allow a relatively free gratification of basic and natural human desires related to enjoying life and having fun, while more restrained societies (e.g., China, Korea, and India) tend to control the satisfaction of needs and regulate it through strict social norms. Research has been very scant on the relationship between indulgence and innovation; Tian et al. [82] highlights the need for more empirical studies to explore their relationship in the future. Indulgent societies have been found to be more optimistic 
and open to information technologies, such as online shopping [83]. There seems to be a positive relationship between indulgence and volunteering [84], and between indulgence and corporate social responsibility [85]. Organizations reporting on the Sustainable Development Goals are more likely to come from countries characterized by a higher level of indulgence [86]. When basic needs are already satisfied, consumers start looking for higher levels of concern, which explains why a country's cultural indulgence is positively related to the eco-innovation index [82].

Hypothesis 6 (H6). Countries with a more indulgent culture have a higher EV adoption rate.

Figure 1 illustrates our conceptual model linking the cultural dimensions to the market share of BEVs.

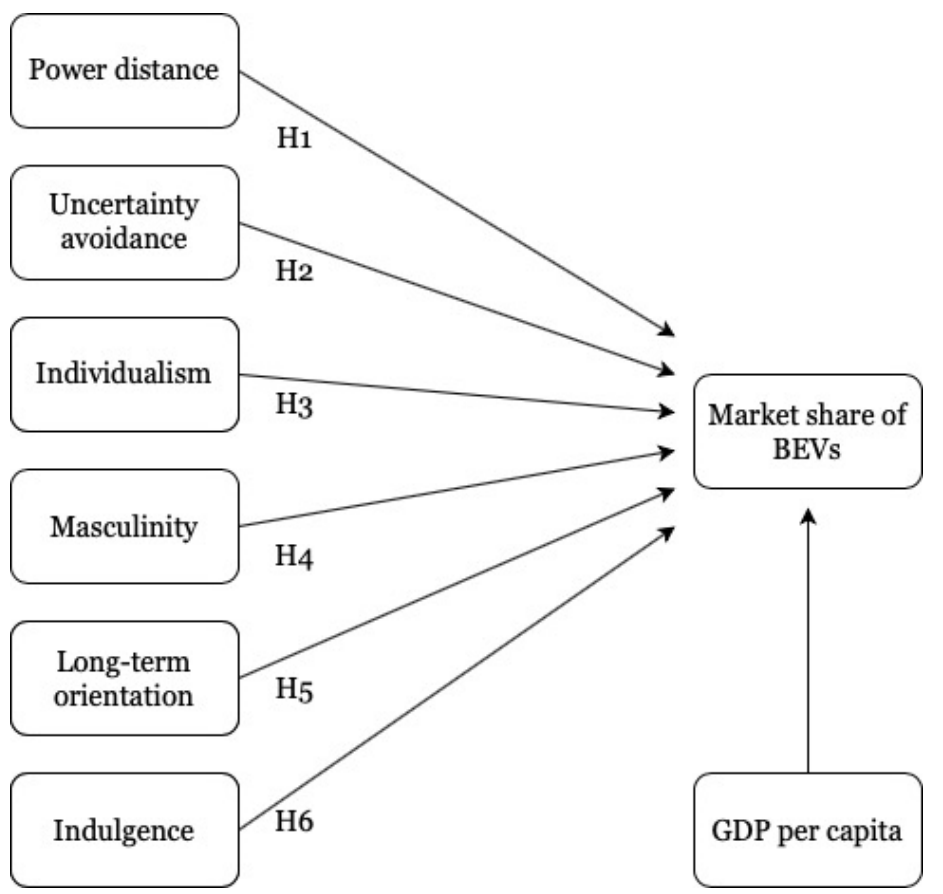

Figure 1. Theoretical model: The impact of cultural dimensions on the adoption of battery electric vehicles.

Based on the literature, we propose that power distance, uncertainty avoidance, individualism, and masculinity negatively, whilst long-term orientation and indulgence positively impact BEV adoption. In addition, we utilise an important (GDP per capita) control variable that is likely to affect BEV adoption in a country.

\section{Data and Method}

The analysis covers 21 countries based on the Global EV Outlook (2020 and 2021) databases, containing data on the Electric Vehicles Initiative (EVI) members. EVI is a multi-government policy forum dedicated to speeding up the introduction and adoption of EVs. The countries included in the analysis are Australia, Brazil, Chile, Finland, France, Holland, India, Japan, Canada, China, Mexico, Germany, New Zealand, Portugal, Sweden, South Africa, South Korea, Thailand, the USA, and the United Kingdom. Since EV sales and production are primarily concentrated in China, Europe, Japan, and the United States, these countries represent most of the international market for EVs [87].

The dependent variable is the market share (\% of total automobile sales) of pure battery EVs (BEVs) in 2019 and 2020. EVs with both battery and internal combustion engines ("hybrid") sell better in most car markets because of their longer driving ranges [88]; thus, vehicles that obtain energy entirely from the battery require a complete shift in the consumer mind-set and represent a more disruptive innovation [89]. BEVs are exciting to study, as 
the automotive industry is typically averse to more radical technological changes [90]. Explanatory variables are the index scores of the various cultural dimensions obtained from the Hofstede databank [91]. The regression models also include output (GDP) per capita at constant USD prices [92] as a suggested control variable to reduce model specification error [93] and to follow Hofstede's recommendations [56]. The descriptive statistics of the variables are reported in Table 1.

Table 1. Descriptive statistics $(n=21)$.

\begin{tabular}{|c|c|c|c|c|c|c|}
\hline Variables & Description & Mean & Median & SD & Min & Max \\
\hline \multicolumn{7}{|c|}{ Dependent variable: } \\
\hline $\mathrm{BEV}$ & $\begin{array}{l}\text { Natural log of the market share of } \\
\text { BEVs (the share of new BEV } \\
\text { registrations as a \% of total new } \\
\text { vehicle registrations) }\end{array}$ & 3.986 & 1.700 & 9.30 & 0.00 & 42.40 \\
\hline \multicolumn{7}{|c|}{ Independent variables: } \\
\hline PDI & Power Distance & 50.95 & 49.00 & 18.25 & 22.00 & 81.00 \\
\hline UAI & Uncertainty Avoidance & 60.76 & 53.00 & 21.28 & 29.00 & 99.00 \\
\hline IDV & Individualism vs. Collectivism & 57.86 & 67.00 & 25.40 & 18.00 & 91.00 \\
\hline MAS & Masculinity vs. Femininity & 47.19 & 52.00 & 22.87 & 5.000 & 95.00 \\
\hline LTO & $\begin{array}{l}\text { Long Term vs. Short } \\
\text { Term Orientation }\end{array}$ & 48.81 & 38.00 & 23.72 & 21.00 & 100.0 \\
\hline IVR & Indulgence vs. Restraint & 56.33 & 59.00 & 19.20 & 24.00 & 97.00 \\
\hline \multicolumn{7}{|c|}{ Control variable: } \\
\hline GDP & Natural log of GDP per capita & 36,081 & 43,712 & 23,743 & 2152 & 92,556 \\
\hline
\end{tabular}

First, we calculated the Pearson correlation coefficients to measure the strength and direction of the linear relationship between variables. Possible values of the correlation coefficient range from -1 to +1 , with -1 indicating a perfectly linear negative, i.e., an inverse correlation, and +1 indicating a perfectly linear positive correlation. A correlation coefficient close to 0 suggests little, if any, correlation. As the Pearson's product-moment correlation does not consider whether a variable is classified as dependent or independent, we ran linear regressions. OLS regression is one of the most widely used methods for fitting linear statistical models. It uses the following formula in matrix form (Equation (1)):

$$
y=X \beta+e
$$

where $y$ is an $n \times 1$ vector of outcome observations, $X$ is the $n \times(p+1)$ matrix of the predictor variable values (including a single column for the regression constant), and e is the $n \times 1$ vector of errors, where $n$ is the sample size and $p$ is the number of predictor variables. Linear parameters were assumed and ordinary least squares (OLS) regression analyses with heteroscedasticity-consistent and robust (HAC) standard errors were estimated to test the hypotheses. According to the Gauss' theorem, the OLS estimator is consistent if the repressors are exogenous in the class of best linear unbiased estimators (BLUE) and the errors are homoscedastic and serially uncorrelated [94]. For cross-sectional data, the most likely deviation from the errors is caused by heteroscedasticity; i.e., non-constant variance. White [95] proposed a heteroscedasticity corrected estimator for the covariance matrix (HCCME) of the parameter estimates that at least asymptotically preserves its validity under undefined heteroscedasticity (Equation (2)). The results of these regression models do not contain heteroscedastic residuals, and the disturbances have the same variance across all observations.

$$
\operatorname{VAR}(\beta)=\left(X^{\prime} X\right)^{-1} X^{\prime} \Omega X\left(X^{\prime} X\right)^{-1}
$$


where $\Omega$ is a diagonal matrix, in which non-zero elements can be estimated by squaring the OLS residuals.

The latest release (30 September 2021) of Gretl (Gnu Regression, Econometrics and Time-series Library), a cross-platform software package for econometric analysis, was used to conduct the regression analysis [96]. Multiple linear regression calculates whether the value of a continuous dependent variable (the market share of EVs) can be predicted from a set of independent variables and the extent of its variance explained by the predictors. The OLS regression selection approach is useful in testing the effect of national culture on EV diffusion in a cross-sectional research design.

The dependent variable and GDP per capita were transformed using the natural log function to decrease skewness and de-emphasise outliers, such as Norway. The model contains six independent variables for a country $(\mathrm{i})$ and national wealth (Equation (3)):

$\mathrm{BEV}_{\mathrm{i}}=\beta_{0}+\beta_{1} \mathrm{PDI}_{\mathrm{i}}+\beta_{2} \mathrm{UAI}_{\mathrm{i}}+\beta_{3} \mathrm{IDV}_{\mathrm{i}}+\beta_{4} \mathrm{MAS}_{\mathrm{i}}+\beta_{5} \mathrm{LTO}_{\mathrm{i}}+\beta_{6} \mathrm{IVR}_{\mathrm{i}}+\beta_{7} \mathrm{GDP}_{\mathrm{i}}+\mathrm{e}_{\mathrm{i}}$

\section{Results}

According to the correlation coefficients (Table 2), there is a significant $(p<0.05)$ negative relationship between BEV adoption and power distance, and wealth per capita is strongly and positively associated with the sales of electric cars $(p<0.001)$. As suggested by Hofstede [56], power distance is negatively $(p<0.001)$, whereas individualism positively relates to wealth (GDP per capita) $(p<0.001)$.

Table 2. Pearson product-moment coefficient correlations $(n=21)$.

\begin{tabular}{|c|c|c|c|c|c|c|c|c|}
\hline & BEV & PDI & UAI & IDV & MAS & LTO & IVR & GDP \\
\hline $\mathrm{BEV}$ & 1 & & & & & & & \\
\hline PDI & $-0.49^{* *}$ & 1 & & & & & & \\
\hline UAI & -0.25 & $0.41^{*}$ & 1 & & & & & \\
\hline IDV & 0.19 & $-0.72 * * *$ & $-0.48^{* *}$ & 1 & & & & \\
\hline MAS & -0.36 & 0.23 & 0.07 & 0.02 & 1 & & & \\
\hline LTO & 0.29 & 0.15 & 0.08 & -0.25 & 0.18 & 1 & & \\
\hline IVR & -0.28 & $-0.39 *$ & -0.16 & $0.48^{* *}$ & -0.08 & $-0.59 * * *$ & 1 & \\
\hline GDP & $0.63^{* * *}$ & $-0.76^{* * *}$ & -0.02 & $0.57^{* * *}$ & -0.22 & 0.06 & 0.31 & 1 \\
\hline
\end{tabular}

We estimated eight regression models, four for 2019 and four for 2020. After testing the effect of GDP per capita, estimates for Hofstede's 4-dimension (4D) [19], 5-dimension (5D) [97], and 6-dimension (6D) [20] models were calculated in both years. The F-tests of overall significance indicate that the regression models fit the data. The variance inflation factor (VIF) values indicate that multicollinearity is not a significant concern. VIF scores remain below the maximum acceptable level of 10 [98] and are even less 5 [99]. DoornikHansen (DH) tests [100] for normality of residuals are acceptable at the $0.05 p$-level. We also calculated correlation coefficients between residuals and independent variables, which show that all independent variables are uncorrelated with the error term $(p>0.05)$.

Statistical power analyses were performed using the $G^{*}$ Power 3.1 software to obtain the probability of correctly rejecting a false null hypothesis [101]. The results in Table 3 show that the lowest adjusted $\mathrm{R}^{2}$ values are 0.54 (M1) and 0.79 (M2). The generally accepted level of the power is 0.8 . However, using these adjusted $\mathrm{R}^{2}$ values, we obtained values of 0.988 and 0.998 for statistical power. Hence, regardless of the small sample size $(n=21)$, our models provide enough power to draw appropriate statistical conclusions. 
Table 3. Estimates of the OLS regression models.

\begin{tabular}{|c|c|c|c|c|c|c|c|c|}
\hline \multirow{3}{*}{$\begin{array}{l}\text { DV: } \\
\text { IVs: }\end{array}$} & \multicolumn{8}{|c|}{ BEV } \\
\hline & \multicolumn{4}{|c|}{2019} & \multicolumn{4}{|c|}{2020} \\
\hline & M1 & M2(4D) & M3(5D) & M4(6D) & M5 & M6(4D) & M7(5D) & M8(6D) \\
\hline \multirow[t]{2}{*}{ Constant } & $-36.34^{* * *}$ & $-26.14^{* * *}$ & $-22.72 * * *$ & $-19.74^{* *}$ & $-25.97 * * *$ & $-35.28^{* * *}$ & $-31.33 * * *$ & $-33.44^{* *}$ \\
\hline & $(-4.83)$ & $(-5.92)$ & $(-7.01)$ & $(-4.03)$ & $(-6.23)$ & $(-8.87)$ & $(-7.97)$ & $(-7.05)$ \\
\hline \multirow[t]{2}{*}{ PDI } & & 0.03 & 0.03 & 0.06 & & $0.06^{* * *}$ & 0.02 & 0.03 \\
\hline & & $(1.17)$ & $(1.54)$ & $(0.96)$ & & (3.44) & $(1.77)$ & (1.68) \\
\hline \multirow[t]{2}{*}{ UAI } & & $-0.09 * * *$ & $-0.06^{* * *}$ & $-0.06^{* * *}$ & & $-0.05^{* * *}$ & $-0.03 * * *$ & $-0.03^{* * *}$ \\
\hline & & $(-6.28)$ & $(-4.79)$ & $(-3.57)$ & & $(-4.60)$ & $(-4.11)$ & $(-4.13)$ \\
\hline \multirow[t]{2}{*}{ IDV } & & $-0.07^{* * *}$ & $-0.03 *$ & -0.01 & & -0.01 & $-0.01 *$ & -0.01 \\
\hline & & $(-5.05)$ & $(-2.03)$ & $(-0.05)$ & & $(-0.85)$ & $(-1.78)$ & $(-0.24)$ \\
\hline \multirow[t]{2}{*}{ MAS } & & -0.01 & $-0.03^{* * *}$ & $-0.04^{* *}$ & & $-0.03^{* * *}$ & $-0.02 * * *$ & $-0.02^{* * *}$ \\
\hline & & $(-1.19)$ & $(-4.47)$ & $(-2.85)$ & & $(-3.93)$ & $(-3.76)$ & $(-3.13)$ \\
\hline \multirow[t]{2}{*}{ LTO } & & & $0.03^{* * *}$ & -0.01 & & & $0.01 * *$ & -0.01 \\
\hline & & & (3.48) & $(-0.05)$ & & & $(2.27)$ & $(-0.24)$ \\
\hline \multirow[t]{2}{*}{ IVR } & & & & $-0.11^{* * *}$ & & & & $-0.03^{* * *}$ \\
\hline & & & & $(-11.28)$ & & & & $(-3.50)$ \\
\hline \multirow[t]{2}{*}{ GDP } & $3.44^{* * *}$ & $3.32 * * *$ & $2.62 * * *$ & $2.94^{* * *}$ & $2.60 * * *$ & $3.70 * * *$ & $3.35^{* * *}$ & $3.74^{* * *}$ \\
\hline & (4.97) & (8.01) & (8.14) & $(4.03)$ & (6.38) & (10.39) & $(10.08)$ & $(9.20)$ \\
\hline $\mathrm{R}^{2}$ & 0.56 & 0.84 & 0.97 & 0.99 & 0.68 & 0.95 & 0.97 & 0.99 \\
\hline Adj. $\mathrm{R}^{2}$ & 0.54 & 0.79 & 0.95 & 0.99 & 0.66 & 0.93 & 0.96 & 0.97 \\
\hline F-value & $24.6^{* * *}$ & $15.8^{* * *}$ & $67.3^{* * *}$ & $544.3^{* * *}$ & $40.7^{* * *}$ & $61.3^{* * *}$ & $104.4^{* * *}$ & $133.0^{* * *}$ \\
\hline $\max (\mathrm{VIF})$ & - & 4.17 & 4.33 & 4.33 & - & 4.14 & 4.29 & 4.31 \\
\hline DH-test & 2.901 & 4.094 & $7.694^{* *}$ & $6.573^{* *}$ & 1.013 & 1.547 & 1.385 & 1.177 \\
\hline Obs. & 21 & 21 & 21 & 21 & 21 & 21 & 21 & 21 \\
\hline
\end{tabular}

Notes: Heteroscedasticity robust (HAC) $t$-statistics of the standard errors are in parentheses. DV: dependent variable, IVs: independent variables. ${ }^{* *}$ : significant at $0.001(p<0.001),{ }^{* *}$ : at $0.05 p$-level, ${ }^{*}$ : at $0.1 p$-level.

Regression coefficients in Table 3 indicate that GDP per capita is a consistent and robust predictor $(p<0.001)$ of BEV adoption; hence its inclusion in the models has been justified. The finding that more well-off societies are more likely to adopt electric cars is not surprising. According to recent research in the EU [102], EV sales strongly correlate with the standard of living. Even in Norway, the country with the highest BEV market share in the world (54\% in 2020), EV ownership is increasing with consumers' wealth, income, and education [103].

We also estimated coefficients for the dimensions of national culture. When accounting for wealth, except for one model (M6), the effect of power distance (PDI) is insignificant (H1 is not supported). This result is unexpected as power distance is linked in the literature with higher wealth, lower innovativeness [75], and lower sustainability [54]. Correlation coefficients in Table 2 also indicate a two-way linear association between PDI and BEV sales; however, after controlling for GDP per capita this link diminishes. In China, for example, both power distance and EV market share are relatively high.

As shown in Table 3, uncertainty avoidance (UAI) strongly and negatively impacts BEV sales ( $\mathrm{H} 2$ is supported), which resonates with prior findings that suggest a positive association between uncertainty acceptance and innovativeness [104]. In our sample, Sweden, China, and the UK have the lowest UAI scores, and all these countries have a relatively high BEV market share. 
Individualism (IDV) has a significant negative impact on BEV sales; however, its effect fades when IVR is introduced to the analysis (IDV and IVR are moderately and positively correlated). The literature is conflicting regarding the role of individualism in EV adoption. Some studies (e.g., [62,82]) associate consumer innovativeness and environmental consciousness with individualistic cultures. Others (e.g., $[65,66])$ show that collectivism influences environmentally friendly behaviours positively. Individualism is prone to be dominant in richer and Western countries, while collectivism prevails in less developed and Eastern countries [56]. We accept H3 based on the estimates of Model 2, 3, and 7.

Masculinity (MAS) has a significant negative impact on BEV sales, as indicated by the coefficients in Table 3 (H4 is supported). Consistent with the extant literature, less masculine cultures are more likely to shift their preferences from traditional cars to electric vehicles. Feminine values, such as empathy and modesty, resonate with the concept of environmental awareness. A recent study conducted in Belgium, Italy, and Denmark [105] also found that women are less self-oriented than men and hence are more likely to develop an environmental self-identity [106]. Kawgan-Kagan [107] suggest that a gender-sensitive perspective is needed to increase the spread of EVs, and our finding also supports this view. In our sample, Norway, the Netherlands, and Sweden are the most feminine cultures, and these nations also have the highest $\mathrm{BEV}$ rates.

Long-term orientation (LTO) has a positive and significant impact in the 5D models (M3 and M7); hence, H5 is supported. However, LTO becomes insignificant when indulgence (IVR) is added, probably because LTO and IVR are moderately related to each other. These two recently established cultural dimensions received insufficient interest so far in the literature. The finding that long-term orientation (LTO) has a positive impact is reasonable as the benefits of transitioning to environmentally friendly technologies are mainly realised by future generations.

Indulgence versus restraint (IVR) measures the extent to which people in a society feel to be free to enjoy life without restraints and regulations. In contradiction to H6, indulgence has a strong negative impact on BEV sales, as shown by Model 4 and 8 (H6 is rejected). While prior findings (e.g., [10]) indicate that indulgent societies are more open to new technologies and environmental concerns, surprisingly, the results show that BEV consumption is significantly higher in more restrained cultures. Consumers in indulgent cultures may feel that electric cars constrain free travelling because of a lower driving range, longer charging times, and a need for carefully planning routes [108]. Escandon-Barbosa et al. [109] show that people in indulgent societies are more anxious and stressed when they have to face a decision to adopt new technologies. Higher perceived costs in terms of altering travel habits and higher anxiety about the buying decision may lead to lower EV growth rates in more indulgent societies.

\section{Conclusions}

In this paper, we examined the impact of national culture on the adoption of electric vehicles (EVs). We aimed to contribute to the research on the factors influencing country differences in EV market share and market development. We covered a relatively large sample of countries, included several cultural dimensions, and tested relationships in two consecutive years (2019 and 2020) to provide more generalizable and robust results and a better understanding of the cross-country differences in the adoption of electric cars. Prior research on the link between culture and the adoption of eco-innovations typically involve only one or a handful of countries. Six hypotheses were tested based on Hofstede's model of national culture using battery electric vehicle (BEV) market share as a dependent variable. We found that culture significantly influences BEV sales, which are more pronounced in countries where cultural values are more conforming to the functional, innovative, and environmental benefits of purchasing and using electric cars. In addition to higher per capita wealth, societies characterised by lower uncertainty avoidance (lower stress when facing the future), collectivism (prioritizing the needs of the group), femininity (more 
modest and caring), long-term orientation (focusing on the future), and restraint (control of desires) are more likely to adopt BEVs.

Our paper has several theoretical contributions. We extended prior research that studied the role of policy incentives and socio-economic factors [8] by providing empirical evidence on the impact of culture on EV market development. The study determined that uncertainty avoidance, masculinity vs. femininity, individualism vs. collectivism, and indulgence vs. restraint have a significant impact on the adoption of battery electric vehicles. Only when cultural impacts are understood, it will be possible to increase EV sales and improve the quality of living, especially in urban areas, by reducing local and global emissions and noise exposure. While we focused on EVs, we also contribute to a better understanding of consumer behaviour and the decision-making process regarding eco-innovations as emphasised by Karakaya et al. [110]. Examining interactions between culture and other aspects of "sustainability transitions", such as technology, policy, and economics, provides better insights about the diffusion process of eco-innovations. The relationship of eco-innovations and culture are reciprocal, as innovations can also change social norms, cultural values, and institutional structures [111].

From a practitioner perspective, findings assist marketers of alternative-fuel vehicles in formulating marketing communication and marketing strategies. Wang and Bansal adopted [112] Hofstede's dimensions of culture to conduct a meta-regression analysis through 170 studies and found that marketers need to apply a fine-grained approach to relationship marketing because of the high level of heterogeneity across different cultural dimensions. When making a purchase, consumers consider costs and benefits. However, much of the benefits of EVs are societal (e.g., reducing local pollution and greenhouse emissions), while the costs are mostly born by the car owner in terms of higher price, lower driving range, and the limited availability of the recharging infrastructure. In addition to supportive national policies, to increase the rate of diffusion, competent marketing is needed throughout the stages of the adoption process [48], while taking national cultural values into consideration. For example, marketing messages in uncertainty-avoidant cultures need to address the risks and anxieties of owning an EV, such as consumers' lack of experience using the technology and especially "range anxiety" [113] associated with an ambiguous driving range and the availability of charging infrastructure [114]. Norway, for example, created a very dense charging network to decrease the fear of being stuck in an isolated region in the winter [115]. An alternative eco-friendly technology, fuel cells vehicles (FCVs), may be more appealing to consumers with range anxiety or ones who cannot charge their vehicle from home [116]. FCVs can become a major competitor to BEVs, as they have lower life-cycle emissions, run higher ranges, and require a shorter time to refuel [117]. In masculine cultures, on the other hand, marketers should pay attention to men's attraction to state-of-the-art technologies. EVs can be portrayed as both feminine and masculine, depending on whether the emphasis is put on practicalities (e.g., convenient places for packing) or on power, speed, and displays of wealth [80]. Cultures change slowly, but the rapid development of EV technology and decreasing overall costs [118] are likely to improve consumer attitudes in countries where cultural values are not yet EV friendly.

A key limitation of our study is the cross-sectional nature of the collected data. A longitudinal study may eliminate the data uncertainty and show how changes in culture impact the adoption of sustainable ways of transportation and other types of eco-innovations over time. However, as national culture is an institutional factor [119], a longitudinal analysis is not easy to implement. Another limitation is that we used only one control variable, per capita income, as recommended by Hofstede. GDP per capita is a complex measure that captures a variety of confounding factors, such as living standards and relative costs of using the technology; therefore, it does not precisely measure the total cost of ownership [120], including the ease of charging and electricity prices in different countries.

Further research can focus on how various cultural dimensions influence adoption behaviour in other markets for eco-innovations related to grand challenges such as zeroemission, zero-plastic, or zero-pesticides. More attention should be paid to the decarbonisa- 
tion of other critical sectors such as aviation, shipping, road freight, and industry through demand reduction [121]. Our research covered the six dimensions of culture as defined by Hofstede et al. [56]; hence, further research can focus on a specific dimension. When a smaller number of cultural dimensions are studied, other explanatory variables (e.g., indices related to national innovativeness and environmental consciousness) and even interactions can be added to the research, which may provide a more nuanced picture for theoretical development and for EV marketers. Similar studies can be performed at the "micro" level to test cultural values at the individual level involving some other potential factors influencing consumer behaviour such as marketing stimuli, consumer psychology, or the stages of the buying decision process. Lastly, a longitudinal study may show how changes in culture impact the adoption of sustainable ways of transportation and other types of eco-innovations over time.

Author Contributions: Conceptualization, A.N. and I.S.; methodology, D.M.; software, D.M.; validation, S.K.; formal analysis, A.N.; investigation, A.N.; resources, D.M.; data curation, I.S.; writingoriginal draft preparation, A.N.; writing-review and editing, D.M.; visualization, A.N.; supervision, A.N.; project administration, D.M.; funding acquisition, D.M. All authors have read and agreed to the published version of the manuscript.

Funding: The APC was funded by the ÚNKP-21-5-DE-78 New National Excellence Program of the Ministry for Innovation and Technology from the source of the National Research, Development and Innovation Fund, Hungary.

Institutional Review Board Statement: Not applicable.

Informed Consent Statement: Not applicable.

Data Availability Statement: Not applicable.

Acknowledgments: This work was supported by the János Bolyai Research Scholarship of the Hungarian Academy of Sciences. This research was supported by the ÚNKP-21-5-DE-78 New National Excellence Program of the Ministry for Innovation and Technology from the source of the National Research, Development and Innovation Fund.

Conflicts of Interest: The authors declare no conflict of interest. The funders had no role in the design of the study; in the collection, analyses, or interpretation of data; in the writing of the manuscript, or in the decision to publish the results.

\section{Abbreviations}

BEV (battery electric vehicle); EV (electric vehicle); EVI (Electric Vehicles Initiative); GDP (gross domestic product); IDV (individualism vs. collectivism); IVR (indulgence vs. restraint); LTO (longterm vs. short-term orientation); MAS (masculinity vs. femininity); PDI (power distance); OECD (Organization for Economic Co-operation and Development); UAI (uncertainty avoidance).

\section{References}

1. Høyer, K.G. The History of Alternative Fuels in Transportation: The Case of Electric and Hybrid Cars. Util. Policy 2008, 16, 63-71. [CrossRef]

2. Khandakar, A.; Rizqullah, A.; Berbar, A.; Ahmed, M.; Iqbal, A.; Chowdhury, M.; Zaman, S. A Case Study to Identify the Hindrances to Widespread Adoption of Electric Vehicles in Qatar. Energies 2020, 13, 3994. [CrossRef]

3. Marinaro, M.; Bresser, D.; Beyer, E.; Faguy, P.; Hosoi, K.; Li, H.; Sakovica, J.; Amine, K.; Wohlfahrt-Mehrens, M.; Passerini, S. Bringing Forward the Development of Battery Cells for Automotive Applications: Perspective of R\&D Activities in China, Japan, the EU and the USA. J. Power Sources 2020, 459, 228073. [CrossRef]

4. Helmers, E.; Marx, P. Electric Cars: Technical Characteristics and Environmental Impacts. Environ. Sci. Eur. 2012, 24, 14. [CrossRef]

5. Energy Agency, I. Global EV Outlook 2021 Accelerating Ambitions Despite the Pandemic; IEA: Paris, France, 2021.

6. Kittner, N.; Tsiropoulos, I.; Tarvydas, D.; Schmidt, O.; Staffell, I.; Kammen, D.M. Electric Vehicles. In Technological Learning in the Transition to a Low-Carbon Energy System; Elsevier: Amsterdam, The Netherlands, 2020; pp. 145-163.

7. Bloomberg, N.E.F. Global EV Outlook 2021: Commercial Vehicles; BloombergNEF: London, UK, 2022. 
8. Xue, C.; Zhou, H.; Wu, Q.; Wu, X.; Xu, X. Impact of Incentive Policies and Other Socio-Economic Factors on Electric Vehicle Market Share: A Panel Data Analysis from the 20 Countries. Sustainability 2021, 13, 2928. [CrossRef]

9. Rennings, K. Redefining Innovation-Eco-Innovation Research and the Contribution from Ecological Economics. Ecol. Econ. 2000, 32, 319-332. [CrossRef]

10. Orlando, B.; Ballestra, L.V.; Scuotto, V.; Pironti, M.; del Giudice, M. The Impact of R\& D Investments on Eco-Innovation: A Cross-Cultural Perspective of Green Technology Management. IEEE Trans. Eng. Manag. 2020, 1-10. [CrossRef]

11. Aloise, P.G.; Macke, J. Eco-Innovations in Developing Countries: The Case of Manaus Free Trade Zone (Brazil). J. Clean. Prod. 2017, 168, 30-38. [CrossRef]

12. Sovacool, B.K.; Griffiths, S. Culture and Low-Carbon Energy Transitions. Nat. Sustain. 2020, 3, 685-693. [CrossRef]

13. Laroche, M.; Teng, L. Understanding the Global Consumer Culture: Views from Eastern and Western Scholars, an Introduction to the Special Issue. J. Bus. Res. 2019, 103, 219-221. [CrossRef]

14. McLeay, F.; Yoganathan, V.; Osburg, V.-S.; Pandit, A. Risks and Drivers of Hybrid Car Adoption: A Cross-Cultural Segmentation Analysis. J. Clean. Prod. 2018, 189, 519-528. [CrossRef]

15. Rezvani, Z.; Jansson, J.; Bodin, J. Advances in Consumer Electric Vehicle Adoption Research: A Review and Research Agenda. Transp. Res. Part D Transp. Environ. 2015, 34, 122-136. [CrossRef]

16. Lee, S.G.; Trimi, S.; Kim, C. The Impact of Cultural Differences on Technology Adoption. J. World Bus. 2013, 48, 20-29. [CrossRef]

17. Minton, E.A.; Spielmann, N.; Kahle, L.R.; Kim, C.-H. The Subjective Norms of Sustainable Consumption: A Cross-Cultural Exploration. J. Bus. Res. 2018, 82, 400-408. [CrossRef]

18. Gnann, T.; Plötz, P. A Review of Combined Models for Market Diffusion of Alternative Fuel Vehicles and Their Refueling Infrastructure. Renew. Sustain. Energy Rev. 2015, 47, 783-793. [CrossRef]

19. Hofstede, G. Culture and Organizations. Int. Stud. Manag. Organ. 1980, 10, 15-41. [CrossRef]

20. Hofstede, G.; Hofstede, G.J.; Minkov, M. Cultures and Organizations: Software of the Mind Intercultural Cooperation and Its Importance for Survival; McGraw-Hill: New York, NY, USA, 2013; ISBN 0071664181.

21. Samarasinghe, R. The Influence of Cultural Values and Environmental Attitudes on Green Consumer Behaviour. Int. J. Behav. Sci. 2012, 7, 83-98.

22. Onel, N.; Mukherjee, A. The Effects of National Culture and Human Development on Environmental Health. Environ. Dev. Sustain. 2014, 16, 79-101. [CrossRef]

23. Barbarossa, C.; Beckmann, S.C.; De Pelsmacker, P.; Moons, I.; Gwozdz, W. A Self-Identity Based Model of Electric Car Adoption Intention: A Cross-Cultural Comparative Study. J. Environ. Psychol. 2015, 42, 149-160. [CrossRef]

24. Moons, I.; de Pelsmacker, P. Emotions as Determinants of Electric Car Usage Intention. J. Mark. Manag. 2012, 28, 195-237. [CrossRef]

25. Komsiyska, L.; Buchberger, T.; Diehl, S.; Ehrensberger, M.; Hanzl, C.; Hartmann, C.; Hölzle, M.; Kleiner, J.; Lewerenz, M.; Liebhart, B.; et al. Critical Review of Intelligent Battery Systems: Challenges, Implementation, and Potential for Electric Vehicles. Energies 2021, 14, 5989. [CrossRef]

26. Genc, T.S.; De Giovanni, P. Dynamic Pricing and Green Investments under Conscious, Emotional, and Rational Consumers. Clean Responsible Consum. 2021, 2, 100007. [CrossRef]

27. Li, L.; Wang, Z.; Li, Y.; Liao, A. Impacts of Consumer Innovativeness on the Intention to Purchase Sustainable Products. Sustain. Prod. Consum. 2021, 27, 774-786. [CrossRef]

28. Ling, Z.; Cherry, C.R.; Wen, Y. Determining the Factors That Influence Electric Vehicle Adoption: A Stated Preference Survey Study in Beijing, China. Sustainability 2021, 13, 11719. [CrossRef]

29. Lin, B.; Wu, W. Why People Want to Buy Electric Vehicle: An Empirical Study in First-Tier Cities of China. Energy Policy 2018, 112, 233-241. [CrossRef]

30. Plötz, P.; Schneider, U.; Globisch, J.; Dütschke, E. Who Will Buy Electric Vehicles? Identifying Early Adopters in Germany. Transp. Res. Part A Policy Pract. 2014, 67, 96-109. [CrossRef]

31. He, X.; Zhan, W. How to Activate Moral Norm to Adopt Electric Vehicles in China? An Empirical Study Based on Extended Norm Activation Theory. J. Clean. Prod. 2018, 172, 3546-3556. [CrossRef]

32. Masiero, G.; Ogasavara, M.H.; Jussani, A.C.; Risso, M.L. Electric Vehicles in China: BYD Strategies and Government Subsidies. RAI Rev. Adm. Inovação 2016, 13, 3-11. [CrossRef]

33. Driscoll, Á.; Lyons, S.; Mariuzzo, F.; Tol, R.S.J. Simulating Demand for Electric Vehicles Using Revealed Preference Data. Energy Policy 2013, 62, 686-696. [CrossRef]

34. Zhang, Y.; Qian, Z.S.; Sprei, F.; Li, B. The Impact of Car Specifications, Prices and Incentives for Battery Electric Vehicles in Norway: Choices of Heterogeneous Consumers. Transp. Res. Part C Emerg. Technol. 2016, 69, 386-401. [CrossRef]

35. Wróblewski, P.; Lewicki, W. A Method of Analyzing the Residual Values of Low-Emission Vehicles Based on a Selected Expert Method Taking into Account Stochastic Operational Parameters. Energies 2021, 14, 6859. [CrossRef]

36. Martins, L.S.; Guimarães, L.F.; Botelho Junior, A.B.; Tenório, J.A.S.; Espinosa, D.C.R. Electric Car Battery: An Overview on Global Demand, Recycling and Future Approaches towards Sustainability. J. Environ. Manag. 2021, 295, 113091. [CrossRef]

37. Ortar, N.; Ryghaug, M. Should All Cars Be Electric by 2025? The Electric Car Debate in Europe. Sustainability 2019, $11,1868$. [CrossRef] 
38. Franzò, S.; Nasca, A. The Environmental Impact of Electric Vehicles: A Novel Life Cycle-Based Evaluation Framework and Its Applications to Multi-Country Scenarios. J. Clean. Prod. 2021, 315, 128005. [CrossRef]

39. Xu, B.; Sharif, A.; Shahbaz, M.; Dong, K. Have Electric Vehicles Effectively Addressed $\mathrm{CO}_{2}$ Emissions? Analysis of Eight Leading Countries Using Quantile-on-Quantile Regression Approach. Sustain. Prod. Consum. 2021, 27, 1205-1214. [CrossRef]

40. Danielis, R.; Rotaris, L.; Giansoldati, M.; Scorrano, M. Drivers' Preferences for Electric Cars in Italy. Evidence from a Country with Limited but Growing Electric Car Uptake. Transp. Res. Part A Policy Pract. 2020, 137, 79-94. [CrossRef]

41. Goel, P.; Sharma, N.; Mathiyazhagan, K.; Vimal, K.E.K. Government Is Trying but Consumers Are Not Buying: A Barrier Analysis for Electric Vehicle Sales in India. Sustain. Prod. Consum. 2021, 28, 71-90. [CrossRef]

42. Ma, S.C.; Fan, Y.; Guo, J.F.; Xu, J.H.; Zhu, J. Analysing Online Behaviour to Determine Chinese Consumers' Preferences for Electric Vehicles. J. Clean. Prod. 2019, 229, 244-255. [CrossRef]

43. Huang, X.; Lin, Y.; Zhou, F.; Lim, M.K.; Chen, S. Agent-Based Modelling for Market Acceptance of Electric Vehicles: Evidence from China. Sustain. Prod. Consum. 2021, 28, 206-217. [CrossRef]

44. Axsen, J.; TyreeHageman, J.; Lentz, A. Lifestyle Practices and Pro-Environmental Technology. Ecol. Econ. 2012, 82, 64-74. [CrossRef]

45. Orlov, A.; Kallbekken, S. The Impact of Consumer Attitudes towards Energy Efficiency on Car Choice: Survey Results from Norway. J. Clean. Prod. 2019, 214, 816-822. [CrossRef]

46. Zhgulev, E.; Bozhuk, S.; Evdokimov, K.; Pletneva, N. Analysis of Barriers to Promotion of Electric Cars on Russian Market. Proc. Eng. Rural. Dev. 2018, 17, 2110-2117.

47. Busse, S.; El Khatib, V.; Brandt, T.; Kranz, J.; Kolbe, L. Understanding the Role of Culture in Ecoinnovation Adoption-An Empirical Crosscountry Comparison. In Proceedings of the International Conference on Information Systems (ICIS 2013): Reshaping Society Through Information Systems Design, Milano, Italy, 15-18 December 2013; Volume 5, pp. 4533-4550.

48. Qian, L.; Yin, J. Linking Chinese Cultural Values and the Adoption of Electric Vehicles: The Mediating Role of Ethical Evaluation. Transp. Res. Part D Transp. Environ. 2017, 56, 175-188. [CrossRef]

49. Jacks, T.; Palvia, P. A Cultural Sociology Perspective on IT Occupational Culture. In Proceedings of the 17th Americas Conference on Information Systems 2011, AMCIS 2011, Detroit, MI, USA, 4 August 2011; Volume 5, pp. 3538-3547.

50. Hofstede, G.; Hofstede, G.J.; Minkov, M. Cultures and Organizations: Software of the Mind, 3rd ed.; MCB UP Ltd.: Bentley, UK, 2005; ISBN 978-0071664189.

51. Yaveroglu, I.S.; Donthu, N. Cultural Influences on the Diffusion of New Products. J. Int. Consum. Mark. 2002, 14, 49-63. [CrossRef]

52. Rinne, T.; Steel, G.D.; Fairweather, J. Hofstede and Shane Revisited. Cross-Cult. Res. 2012, 46, 91-108. [CrossRef]

53. Katz, J.P.; Swanson, D.L.; Nelson, L.K. Culture-Based Expectations of Corporate Citizenship: A Propositional Framework and Comparison of Four Cultures. Int. J. Organ. Anal. 2001, 9, 149-171. [CrossRef]

54. Kumar, S.; Giridhar, V.; Sadarangani, P. A Cross-National Study of Environmental Performance and Culture: Implications of the Findings and Strategies. Glob. Bus. Rev. 2019, 20, 1051-1068. [CrossRef]

55. Husted, B.W. Culture and Ecology: A Cross-National Study of the Determinants of Environmental Sustainability. Manag. Int. Rev. 2005, 45, 349-371.

56. Hofstede, G. Dimensionalizing Cultures: The Hofstede Model in Context. Online Read. Psychol. Cult. 2011, 2, 2307-0919. [CrossRef]

57. Akbar, U.; Popp, J.; Khan, H.; Khan, M.A.; Oláh, J. Energy Efficiency in Transportation along with the Belt and Road Countries. Energies 2020, 13, 2607. [CrossRef]

58. Steenkamp, J.-B.E.M.; ter Hofstede, F.; Wedel, M. A Cross-National Investigation into the Individual and National Cultural Antecedents of Consumer Innovativeness. J. Mark. 1999, 63, 821-838. [CrossRef]

59. Park, M.-J.; Kim, M.-J. A Cross-Cultural Analysis of Online Satisfaction, Service Failure and Recovery: An E-A-S-QUAL Approach. J. Korean Soc. Cloth. Text. 2011, 35, 700-711. [CrossRef]

60. Parboteeah, K.P.; Addae, H.M.; Cullen, J.B. Propensity to Support Sustainability Initiatives: A Cross-National Model. J. Bus. Ethics 2012, 105, 403-413. [CrossRef]

61. Vachon, S. International Operations and Sustainable Development: Should National Culture Matter? Sustain. Dev. 2010, 18, 350-361. [CrossRef]

62. Taylor, M.Z.; Wilson, S. Does Culture Still Matter? The Effects of Individualism on National Innovation Rates. J. Bus. Ventur. 2012, 27, 234-247. [CrossRef]

63. Soyez, K. How National Cultural Values Affect Pro-environmental Consumer Behavior. Int. Mark. Rev. 2012, 29, 623-646. [CrossRef]

64. Nguyen, T.N.; Lobo, A.; Greenland, S. The Influence of Cultural Values on Green Purchase Behaviour. Mark. Intell. Plan. 2017, 35, 377-396. [CrossRef]

65. Halder, P.; Hansen, E.N.; Kangas, J.; Laukkanen, T. How National Culture and Ethics Matter in Consumers' Green Consumption Values. J. Clean. Prod. 2020, 265, 121754. [CrossRef]

66. Higueras-Castillo, E.; Liébana-Cabanillas, F.J.; Muñoz-Leiva, F.; Molinillo, S. The Role of Collectivism in Modeling the Adoption of Renewable Energies: A Cross-Cultural Approach. Int. J. Environ. Sci. Technol. 2019, 16, 2143-2160. [CrossRef] 
67. Tian, M.; Chapa, S.; Walsh, M.; Kjaerholt, N. Ailin Xia Are Eco-Friendly Cars More Favorable? An Exploratory Study of Attitude toward Eco-Friendliness among Multiethnic Consumers. In Proceedings of the Association of Marketing Theory and Practice Proceedings 2020, online, 6-8 August 2020; pp. 1-23.

68. Kaasa, A.; Vadi, M. How Does Culture Contribute to Innovation? Evidence from European Countries. Econ. Innov. New Technol. 2010, 19, 583-604. [CrossRef]

69. Khan, R.; Cox, P. Country Culture and National Innovation. Arch. Bus. Res. 2017, 5, 85-101. [CrossRef]

70. Bhagat, R.S.; Hofstede, G. Culture's Consequences: Comparing Values, Behaviors, Institutions, and Organizations across Nations. Acad. Manag. Rev. 2002, 27, 460-462. [CrossRef]

71. Park, H.; Russell, C.; Lee, J. National Culture and Environmental Sustainability: A Cross-National Analysis. J. Econ. Financ. 2007, 31, 104-121. [CrossRef]

72. Palmer, K.; Oates, W.E.; Portney, P.R. Tightening Environmental Standards: The Benefit-Cost or the No-Cost Paradigm? J. Econ. Perspect. 1995, 9, 119-132. [CrossRef]

73. Anfinsen, M.; Lagesen, V.A.; Ryghaug, M. Green and Gendered? Cultural Perspectives on the Road towards Electric Vehicles in Norway. Transp. Res. Part D Transp. Environ. 2019, 71, 37-46. [CrossRef]

74. Scharff, V. Femininity and the Electric Car; Free Press: New York, NY, USA, 1991.

75. Yeniyurt, S.; Townsend, J.D. Does Culture Explain Acceptance of New Products in a Country? Int. Mark. Rev. 2003, 20, 377-396. [CrossRef]

76. Ziefle, M.; Beul-Leusmann, S.; Kasugai, K.; Schwalm, M. Public Perception and Acceptance of Electric Vehicles: Exploring Users' Perceived Benefits and Drawbacks. In Lecture Notes in Computer Science (Including Subseries Lecture Notes in Artificial Intelligence and Lecture Notes in Bioinformatics); Springer: Berlin/Heidelberg, Germany, 2014; Volume 8519, pp. 628-639. ISBN 9783319076348.

77. Triandis, H.C.; Hofstede, G. Cultures and Organizations: Software of the Mind. Adm. Sci. Q. 1993, 38, 132-134. [CrossRef]

78. Bukowski, A.; Rudnicki, S. Not Only Individualism: The Effects of Long-Term Orientation and Other Cultural Variables on National Innovation Success. Cross-Cult. Res. 2019, 53, 119-162. [CrossRef]

79. Gul, M.C. Long-Term Orientation, Perceived Consumer Effectiveness, and Environmentally Conscious Consumer Behavior: The Case of Turkey. Int. J. Mark. Stud. 2013, 5, 24-30. [CrossRef]

80. Dou, J.; Su, E.; Wang, S. When Does Family Ownership Promote Proactive Environmental Strategy? The Role of the Firm's Long-Term Orientation. J. Bus. Ethics 2019, 158, 81-95. [CrossRef]

81. Sarigöllü, E. A Cross-Country Exploration of Environmental Attitudes. Environ. Behav. 2009, 41, 365-386. [CrossRef]

82. Tian, M.; Deng, P.; Zhang, Y.; Salmador, M.P. How Does Culture Influence Innovation? A Systematic Literature Review. Manag. Decis. 2018, 56, 1088-1107. [CrossRef]

83. Yıldırım, E.; Arslan, Y.; Barutçu, M.T. The Role of Uncertainty Avoidance and Indulgence as Cultural Dimensions on Online Shopping Expenditure. Eurasian Bus. Econ. J. 2016, 4, 42-51. [CrossRef]

84. Luria, G.; Cnaan, R.A.; Boehm, A. National Culture and Prosocial Behaviors. Nonprofit Volunt. Sect. Q. 2015, 44, 1041-1065. [CrossRef]

85. Halkos, G.; Skouloudis, A. Corporate Social Responsibility and Innovative Capacity: Intersection in a Macro-Level Perspective. J Clean. Prod. 2018, 182, 291-300. [CrossRef]

86. Rosati, F.; Faria, L.G.D. Addressing the SDGs in Sustainability Reports: The Relationship with Institutional Factors. J. Clean. Prod. 2019, 215, 1312-1326. [CrossRef]

87. Lutsey, N.P.; Grant, M.; Wappelhorst, S.; Zhou, H. Power Play: How Governments Are Spurring the Electric; ICCT: Washington, DC, USA, 2018

88. Woo, J.R.; Magee, C.L. Forecasting the Value of Battery Electric Vehicles Compared to Internal Combustion Engine Vehicles: The Influence of Driving Range and Battery Technology. Int. J. Energy Res. 2020, 44, 6483-6501. [CrossRef]

89. Shim, D.; Kim, S.; Altmann, J.; Yoon, Y.; Kim, J. Key Features of Electric Vehicle Diffusion and Its Impact on the Korean Power Market. Sustainability 2018, 10, 1941. [CrossRef]

90. Dijk, M.; Yarime, M. The Emergence of Hybrid-Electric Cars: Innovation Path Creation through Co-Evolution of Supply and Demand. Technol. Forecast. Soc. Change 2010, 77, 1371-1390. [CrossRef]

91. Hofstede, G.; Hofstede, G.; Minkov, J. Cultures and Organizations: Software of the Mind, 3rd ed.; McGraw-Hill: New York, NY, USA, 2010; ISBN 978-0071664189.

92. World Bank World Development Indicators I DataBank. Available online: https://databank.worldbank.org/data/source/worlddevelopment-indicators (accessed on 11 May 2021).

93. Meyer, D.F.; Hassan, A. An Assessment of the Impact of Various Macro-Economic Variables on the Manufacturing Sector: The Case of the Visegrád Four. J. East. Eur. Cent. Asian Res. JEECAR 2020, 7, 351-362. [CrossRef]

94. Johnson, R.A.; Wichern, D.W. Applied Multivariate Statistical Analysis; Pearson: London, UK, 2002; p. 767.

95. White, H. A Heteroskedasticity-Consistent Covariance Matrix Estimator and a Direct Test for Heteroskedasticity. Econometrica 1980, 48, 817-838. [CrossRef]

96. Allin, C.; Riccardo, J.L. Gretl User's Guide: Gnu Regression, Econometrics and Time-Series Library; Free Software Foundation: Boston, MA, USA, 2014

97. Hofstede, G.; Bond, M.H. The Confucius Connection: From Cultural Roots to Economic Growth. Organ. Dyn. 1988, 16, 5-21. [CrossRef] 
98. Hair, J.; Black, B.; Babin, B.; Anderson, R. Multivariate Data Analysis; Pearson: New York, NY, USA, $2010 ;$ ISBN 0135153093.

99. Diamantopoulos, A.; Winklhofer, H.M. Index Construction with Formative Indicators: An Alternative to Scale Development. J. Mark. Res. 2001, 38, 269-277. [CrossRef]

100. Doornik, J.A.; Hansen, H. An Omnibus Test for Univariate and Multivariate Normality. Oxf. Bull. Econ. Stat. 2008, 70, 927-939. [CrossRef]

101. Faul, F.; Erdfelder, E.; Buchner, A.; Lang, A.-G. Statistical Power Analyses Using G*Power 3.1: Tests for Correlation and Regression Analyses. Behav. Res. Methods 2009, 41, 1149-1160. [CrossRef]

102. ACEA Automobile Industry Pocket Guide 2021-2022. ACEA: Brussels, Belgium, 2021.

103. Fevang, E.; Figenbaum, E.; Fridstrøm, L.; Halse, A.H.; Hauge, K.E.; Johansen, B.G.; Raaum, O. Who Goes Electric? The Anatomy of Electric Car Ownership in Norway. Transp. Res. Part D Transp. Environ. 2021, 92, 102727. [CrossRef]

104. Belkhamza, Z.; Azizi Wafa, S. The Role of Uncertainty Avoidance on E-Commerce Acceptance across Cultures. Int. Bus. Res. 2014, 7, 166. [CrossRef]

105. Barbarossa, C.; De Pelsmacker, P.; Moons, I. Personal Values, Green Self-Identity and Electric Car Adoption. Ecol. Econ. 2017, 140, 190-200. [CrossRef]

106. Van der Werff, E.; Steg, L.; Keizer, K. I Am What I Am, by Looking Past the Present. Environ. Behav. 2014, 46, 626-657. [CrossRef]

107. Kawgan-Kagan, I. Are Women Greener than Men? A Preference Analysis of Women and Men from Major German Cities over Sustainable Urban Mobility. Transp. Res. Interdiscip. Perspect. 2020, 8, 100236. [CrossRef]

108. Pojani, D.; Stead, D. Sustainable Urban Transport in the Developing World: Beyond Megacities. Sustainability 2015, 7, 7784-7805. [CrossRef]

109. Escandon-Barbosa, D.; Salas-Paramo, J.; Meneses-Franco, A.I.; Giraldo- Gonzalez, C. Adoption of New Technologies in Developing Countries: The Case of Autonomous Car between Vietnam and Colombia. Technol. Soc. 2021, 66, 101674. [CrossRef]

110. Karakaya, E.; Hidalgo, A.; Nuur, C. Diffusion of Eco-Innovations: A Review. Renew. Sustain. Energy Rev. 2014, 33, 392-399. [CrossRef]

111. Kowalska, A. Implementing Eco-Innovations. Determinants and Effects. Rocz. Nauk. Stowarzyszenia Ekon. Rol. Agrobiz. 2014, 16, 153-158. [CrossRef]

112. Wang, T.; Bansal, P. Social Responsibility in New Ventures: Profiting from a Long-Term Orientation. Strateg. Manag. J. 2012, 33, 1135-1153. [CrossRef]

113. Fernández, R.Á.; Cilleruelo, F.B.; Martínez, I.V. A New Approach to Battery Powered Electric Vehicles: A Hydrogen Fuel-CellBased Range Extender System. Int. J. Hydrog. Energy 2016, 41, 4808-4819. [CrossRef]

114. Mashhoodi, B.; van der Blij, N. Drivers' Range Anxiety and Cost of New EV Chargers in Amsterdam: A Scenario-Based Optimization Approach. Ann. GIS 2021, 27, 87-98. [CrossRef]

115. Viola, F. Electric Vehicles and Psychology. Sustainability 2021, 13, 719. [CrossRef]

116. Hardman, S.; Tal, G. Who Are the Early Adopters of Fuel Cell Vehicles? Int. J. Hydrogen Energy 2018, 43, 17857-17866. [CrossRef]

117. Yu, H.; Yin, J.; Wang, C.; Shen, S.; Yan, X.; Zhang, J. Energy Consumption, Emission and Economy Analysis of Fuel Cell Vehicle in China. IOP Conf. Ser. Earth Environ. Sci. 2021, 687, 012191. [CrossRef]

118. Weiss, M.; Zerfass, A.; Helmers, E. Fully Electric and Plug-in Hybrid Cars-An Analysis of Learning Rates, User Costs, and Costs for Mitigating $\mathrm{CO}_{2}$ and Air Pollutant Emissions. J. Clean. Prod. 2019, 212, 1478-1489. [CrossRef] [PubMed]

119. North, D.C. Institutions, Ideology, and Economic Performance. Cato J. 1991, 11, 477-496.

120. Karlsson, S. What Are the Value and Implications of Two-Car Households for the Electric Car? Transp. Res. Part C Emerg. Technol. 2017, 81, 1-17. [CrossRef]

121. Sharmina, M.; Edelenbosch, O.Y.; Wilson, C.; Freeman, R.; Gernaat, D.E.H.J.; Gilbert, P.; Larkin, A.; Littleton, E.W.; Traut, M.; van Vuuren, D.P.; et al. Decarbonising the Critical Sectors of Aviation, Shipping, Road Freight and Industry to Limit Warming to 1.5-2 ${ }^{\circ}$ C. Clim. Policy 2021, 21, 455-474. [CrossRef] 